\title{
Cell cycle activity of neural precursors in the diseased mammalian brain
}

\author{
Sara Bragado Alonso ${ }^{\dagger}$, Max Schulze-Steikow $^{\dagger}$ and Federico Calegari*
}

DFG-Research Center and Cluster of Excellence for Regenerative Therapies, Dresden, Germany

\section{Edited by:}

Luca Bonfanti, University of Turin, Italy

Reviewed by:

Claudio Giachino, University of Basel, Switzerland

Giovanna Ponti, University of Turin, Italy

\section{${ }^{*}$ Correspondence:}

Federico Calegari, DFG-Research

Center and Cluster of Excellence for Regenerative Therapies,

TU-Dresden., Fetscherstrasse 105,

01307 Dresden, Germany

e-mail: federico.calegari@

crt-dresden.de

${ }^{\dagger}$ Joint first authors.
Basic research during embryonic development has led to the identification of general principles governing cell cycle progression, proliferation and differentiation of mammalian neural stem cells (NSC). These findings were recently translated to the adult brain in an attempt to identify the overall principles governing stemness in the two contexts and allowing us to manipulate the expansion of NSC for regenerative therapies. However, and despite a huge literature on embryonic neural precursors, very little is known about cell cycle parameters of adult neural, or any other somatic, stem cell. In this review, we briefly discuss the long journey of NSC research from embryonic development to adult homeostasis, aging and therapy with a specific focus on their quiescence and cell cycle length in physiological conditions and neurological disorders. Particular attention is given to a new important player in the field, oligodendrocyte progenitors, while discussing the limitation hampering further development in this challenging area.

Keywords: cell cycle, neural stem cells, oligodendrocyte precursor cell (OPC), neurodegenerative diseases, adult neurogenesis

\section{INTRODUCTION}

The study of the cell cycle is one of the most prolific areas in developmental neuroscience with hundreds of publications spanning half a century and contributing new methodologies, basic knowledge and a deeper understanding of brain development and evolution (Fujita, 1962; Schultze and Korr, 1981; Takahashi et al., 1995; Dehay and Kennedy, 2007; Salomoni and Calegari, 2010; Borrell and Calegari, in press).

Cell cycle regulation in itself is a huge field and several reviews already discussed its molecular control during brain development and adulthood (Dehay and Kennedy, 2007; Salomoni and Calegari, 2010; Beukelaers et al., 2011b). As one factor fuelling interest in this area, short cell cycles were found to correlate with a higher proliferative potential of neural precursors at the cellular and tissue level and across phylogeny (Borrell and Calegari, in press). This correlation led to functional manipulations showing that the proliferative potential of neural precursors is increased by shortening their cell cycle while, conversely, lengthening it leads to differentiation and neurogenesis (Calegari and Huttner, 2003; Lange et al., 2009; Pilaz et al., 2009; Artegiani et al., 2011; Beukelaers et al., 2011a).

Considering that the first calculation of the cell cycle during development coincided with the first report on adult neurogenesis five decades ago (Altman, 1962; Fujita, 1962) and that immense efforts are currently invested worldwide in stem cell research and regenerative medicine, it comes as a surprise that cell cycle studies during adulthood, contrary to development, are extremely limited with only a handful addressing the diseased brain. Here we summarize our knowledge on cell cycle parameters of adult neural precursors in physiological and pathological conditions with particular attention to a new player in biomedicine, oligodendrocyte progenitors. This is important to identify potential correlations of biological significance and to identify our gaps in knowledge that the field should address in the years to come.

\section{NEUROGENIC PRECURSORS CELL CYCLE IN PHYSIOLOGICAL CONDITIONS}

Mammalian NSC generate neurons and glia throughout life within two restricted areas: the subgranular zone (SGZ) of the dentate gyrus and the subventricular zone (SVZ) of the lateral ventricles (Zhao et al., 2008; Kriegstein and Alvarez-Buylla, 2009). In both niches a pool of NSC, progenitors and neuroblasts coexist in a dynamic system in which the production of neurons is regulated by intrinsic and extrinsic factors (Lois and AlvarezBuylla, 1994; Cameron and McKay, 2001). Similarly to their embryonic precursors (Merkle et al., 2004; Li et al., 2013), adult NSC maintain a radial morphology (Doetsch et al., 1999; Seri et al., 2001), contact blood vessels (Palmer et al., 2000; Tavazoie et al., 2008) and share common markers (Kriegstein and AlvarezBuylla, 2009). However, in contrast to embryonic development no unique marker has been identified that exclusively labels one, but not others, precursor types (Ming and Song, 2011). In addition, no positive marker of quiescent cells is available to date. These limitations, together with the fact that a significant proportion of NSC are quiescent, makes it remarkably difficult to assess cell cycle parameters during adulthood.

In the SGZ, dividing NSC (type 1) give rise to intermediate progenitors (type 2) that in turn generate neuroblasts (type 3 ) producing granule neurons (Seri et al., 2001; Kempermann et al., 2004). The significance of adult hippocampal neurogenesis is not fully understood but evidence points to a role in learning and memory (Kempermann, 2008; Deng et al., 2010). With regard to the lineage of hippocampal NSC, studies have calculated that type 1 cells undergo 3-4 asymmetric divisions before becoming 
postmitotic astrocytes (Encinas et al., 2011) while others have concluded that at least some type 1 cells can self-renew unlimited times throughout life (Bonaguidi et al., 2011). Despite this controversy, studies attempting to measure the cell cycle in the adult hippocampus found that cycling NSC divide every about 1 day (Lugert et al., 2010; Encinas et al., 2011; Brandt et al., 2012) with $\mathrm{S}$ being the most variable phase among progenitors (Brandt et al., 2012). In particular, type 1 cells complete the cell cycle in $23 \mathrm{~h}$ with an S-phase of $10 \mathrm{~h}$ (Brandt et al., 2012). Subsequently, type 2 cells lengthen to $27 \mathrm{~h}$ while type 3 shorten again to $23 \mathrm{~h}$. Although G1, G2, and M were not individually measured, cell cycle differences were found to be almost exclusively due to S-phase (Table 1) (Brandt et al., 2012).

The SVZ is the second and most proliferative neurogenic niche of the adult mammalian brain (Kriegstein and Alvarez-Buylla, 2009; Ming and Song, 2011). Here, NSC (B cells) have an apical process intercalating between ependymal cells and contacting the ventricle (Mirzadeh et al., 2008) and a basal process contacting blood vessels (Shen et al., 2008). B cells give rise to amplifying progenitors ( $\mathrm{C}$ cells) that generate migrating neuroblasts (A cells) dividing along the SVZ and rostral migratory stream toward the olfactory bulb where they ultimately differentiate into neurons (Petreanu and Alvarez-Buylla, 2002; Ming and Song, 2011). At any given time, B cells represent $10 \%$ of all cycling cells (Doetsch et al., 2002) with a similar proportion being cycling as opposed to quiescent (Ponti et al., 2013). B cells complete the cell cycle in $18 \mathrm{~h}$ and $\mathrm{Gl}$ and $\mathrm{S}$ in 8 and $5 \mathrm{~h}$, respectively (Table $\mathbf{1}$ ) (Ponti et al., 2013). Regarding C cells, these represent over $60 \%$ of proliferating cells (Doetsch et al., 2002) with nearly $90 \%$ of them cycling at any given time (Ponti et al., 2013). C cells are proposed to divide symmetrically 2-3 times before generating A cells and have more heterogeneous cell cycles of 17-22 h, a longer S-phase of 12-15 h and a remarkably short G1 of $2 \mathrm{~h}$ (Ponti et al., 2013). Finally, A cells account for $26 \%$ of dividing cells in the SVZ (Doetsch et al., 2002), have a cell cycle similar to C cells with perhaps a longer G1 (2-5 h) and shorter S of $10 \mathrm{~h}$ (Table 1) (Ponti et al., 2013).

Altogether, cell cycle differences within neurogenic niches seem minor with the only consistent change being a lengthening of S-phase from NSC to progenitors and shortening from progenitors to neuroblasts. Not only is the significance of such changes unknown but no parallelism is evident between embryonic and adulthood precursors because in the former S-phase was found to be longer in NSC than in progenitors (Arai et al., 2011) and G1 during adulthood was found to length from $\mathrm{C}$ to A cells but not from B to C cells (Ponti et al., 2013).

\section{CELL CYCLE IN PATHOLOGICAL CONDITIONS}

Neural progenitors increase their proliferation, meant both as exiting quiescence and shortening the cell cycle, under pathological conditions in both neurogenic niches (Dash et al., 2001; Arvidsson et al., 2002). Most studies focused on the SVZ where neural precursors change their migration and are redirected to the injured area to acquire the phenotype of local cells (Arvidsson et al., 2002), thus, making the SVZ a potential target of therapy. Increased proliferation and altered migration were found in rodent models of multiple sclerosis (Rasmussen et al., 2011; Mecha et al., 2013), Huntington's disease (Tattersfield et al.,
2004), Parkinson (Aponso et al., 2008) and stroke (Thored et al., 2006), the latter of which was also shown in humans (Jin et al., 2006; Minger et al., 2007). Among these diseases, the neurogenic response triggered by stroke is the most prominent and best characterized.

Stroke is a cerebrovascular accident resulting in a permanent damage and second leading cause of death worldwide (WHO, 2013). Two days after striatal stroke, SVZ precursors shorten the cell cycle form 19 to $12 \mathrm{~h}$ due to a shorter G1 from 13 to $8 \mathrm{~h}$ and $\mathrm{S}$ from 5 to $2 \mathrm{~h}$ (Table 1) (Zhang et al., 2006, 2008). Subsequently, cell cycle progressively lengthens reaching normal values 14 days after stroke. Interestingly, the proportion of proliferative, as opposed to differentiative, divisions increases (from 10 to $50 \%$ ) during the period of short cell cycles and, conversely, decreases (back to 10\%) during the long ones (Zhang et al., 2008) although it is important to note that in these studies precursor types were not distinguished and that these values refer to the total SVZ population. Nevertheless, stroke results in an increasing cohort of neuroblasts migrating from the SVZ toward the striatum with a peak at day 14 (Zhang et al., 2004) and lasting for at least 4 months (Arvidsson et al., 2002; Thored et al., 2006; Yamashita et al., 2006). Most of these newborn neurons undergo apoptosis but those that survive functionally integrate (Yamashita et al., 2006; Hou et al., 2008) with evidence indicating that this endogenous neurogenesis can contribute to functional recovery after stroke since, for instance, ablation of neural precursors impairs recovery (Jin et al., 2010; Sun et al., 2013). Yet, it still has to be shown whether an artificial increase in endogenous neurogenesis would favor brain function.

Altogether, cell cycle parameters of precursor cells after stroke recapitulate embryonic development in the sense that short cell cycles are coupled to proliferation and long cell cycles to differentiation. In this context, cell cycle re-entry is likely instrumental to guide the stroke-induced neurogenic response and, in fact, activation of cell cycle regulators is known to occur in both rodents and humans (Love, 2003; Rashidian et al., 2007). Yet, this response in postmitotic neurons is likely to induce apoptosis rather than cell cycle re-entry (Rashidian et al., 2007). This is supported by the fact that injecting a cdk inhibitor in the ischemic area reduces apoptosis and extension of the ischemic core (Osuga et al., 2000) suggesting that cell cycle regulators have different effects in postmitotic neurons or precursors, which should be considered in manipulations aimed to improve recovery. In this context, increasing the endogenous pool of neurogenic precursors by manipulating their cell cycle seems a promising approach to therapy. Moreover, other targets have recently emerged including ependymal cells (Carlen et al., 2009) and glial precursors (Zhang et al., 2011). To our knowledge cell cycle of ependymal cells during neurodegeneration has not been assessed while some groups are now pioneering the study of gliogenesis.

\section{GLIOGENIC PRECURSORS}

\section{CELL CYCLE IN PHYSIOLOGICAL CONDITIONS}

Astrocytes and oligodendrocytes are the most abundant cell type of the adult brain with the latter gaining more interest for their role and potential use during brain recovery (Richardson et al., 2011; Tsai et al., 2012). 
Table 1 | Cell cycle parameters of neurogenic and oligodendrogenic precursors.

\begin{tabular}{|c|c|c|c|c|c|c|c|}
\hline precursors & CNS area & $\begin{array}{l}\text { cell or } \\
\text { tissue type }\end{array}$ & GF (\%) & G1 & s & $\mathrm{G} 2+\mathrm{M}$ & cell cycle \\
\hline \multirow{7}{*}{$\begin{array}{l}\text { neurogenic } \\
\text { precursors }\end{array}$} & \multirow{3}{*}{ hippocampus } & type 1 & - & - & $10 \mathrm{~h}$ & - & $23 \mathrm{~h}$ \\
\hline & & type 2 & - & - & $14 \mathrm{~h}$ & - & $27 \mathrm{~h}$ \\
\hline & & type 3 & - & - & $10 \mathrm{~h}$ & - & $23 \mathrm{~h}$ \\
\hline & \multirow{4}{*}{ SVZ } & $B$ cells & 9 & $8 \mathrm{~h}$ & $5 \mathrm{~h}$ & $6 \mathrm{~h}$ & $18 \mathrm{~h}$ \\
\hline & & $\mathrm{C}$ cells & 87 & $2 \mathrm{~h}$ & $12-15 h$ & $4 \mathrm{~h}$ & $17-22 \mathrm{~h}$ \\
\hline & & A cells & - & $2-5 h$ & $9-11 \mathrm{~h}$ & $4 \mathrm{~h}$ & $17-20 \mathrm{~h}$ \\
\hline & & total cells & $\begin{array}{l}20 \\
\quad 24\end{array}$ & $13 \mathrm{~h} \quad 8 \mathrm{~h}$ & $\stackrel{4-5 h}{2 h}$ & $2 \mathrm{~h} \quad 2 \mathrm{~h}$ & $19 \mathrm{~h}$ \\
\hline \multirow{4}{*}{$\begin{array}{l}\text { oligodendrogenic } \\
\text { precursors }\end{array}$} & \multirow{2}{*}{ brain } & $\begin{array}{l}\text { white } \\
\text { matter }\end{array}$ & $30-99$ & - & $0.8 d$ & - & $10 d$ \\
\hline & & grey matter & $50-98$ & - & $1 d$ & $4 d^{*}$ & $36 \mathrm{~d}$ \\
\hline & \multirow{2}{*}{ spinal cord } & $\begin{array}{l}\text { white } \\
\text { matter }\end{array}$ & 99 & - & $1.1 \mathrm{~d}$ & - & $15 d$ \\
\hline & & grey matter & 99 & - & $0.8 d$ & - & $27 d$ \\
\hline
\end{tabular}

Left to right: precursor types in different areas of the CNS and individual cell types or tissues are indicated with proportion of cycling cells (growth fraction, GF), length of individual phases and total cell cycle in hours (h) or days (d). Split cells indicate values calculated in physiological (left) or pathological (right) conditions. OPC values were acquired at the age of approximately 2 months. *Value calculated from (Simon et al., 2011; Young et al., 2013).

Oligodendrocyte progenitor cells (OPC) play pivotal roles in CNS development (Richardson et al., 2006) and adulthood where they represent the most abundant and homogeneously distributed cycling cell population of the CNS (Richardson et al., 2011). Oligodendrocytes during development are generated from different regions in consecutive waves but it is unknown whether each population has any specific role in brain function (Kessaris et al., 2006). Adult OPC represent 8 and $2 \%$ of the white and gray matter, respectively (Dawson, 2003; Rivers et al., 2008) with resident and migrating OPC in the SVZ and septum giving rise to mature myelinating oligodendrocytes in physiological and pathological conditions (Menn et al., 2006). Maturation of OPC involves changes in morphology and marker expression including Pdgfra, Ng2 for OPC and Olig2 and Sox10 for the whole lineage (Fumagalli et al., 2011). OPC are reactive to neurotransmitters (Bergles et al., 2000; Stevens et al., 2002) and display highly dynamic behavior with regard to migration, filopodia extension, proliferation, differentiation and reaction to injury (Hughes et al., 2013).

Starting at postnatal day 7 and during adulthood, approximately $50-80 \%$ of OPC in the whole brain were described as cycling based on BrdU incorporation (Rivers et al., 2008; Psachoulia et al., 2009; Simon et al., 2011). Another report based on EdU however calculated a growth fraction of about $99 \%$
(Young et al., 2013) but this thymidine analog has raised concern with regard to toxicity (Ponti et al., 2013). Cell cycle length of OPC differs among brain regions and is significantly longer than that of neurogenic precursors. In the white matter, in particular corpus callosum, OPC cell cycle linearly increases from 2 days at 1 week postnatal to a plateau of 150 days at 8 months (Rivers et al., 2008; Psachoulia et al., 2009; Young et al., 2013) with the spinal cord white matter yielding comparable results (Table 1) (Young et al., 2013). In the cortical gray matter cell cycle length was estimated to be about 37 days at 2 months (Simon et al., 2011; Young et al., 2013) with S/G2/M of 5 days (Simon et al., 2011). Cell cycle in the cortex also showed a decrease similar to the corpus callosum with the important difference that a plateau is not reached and cell cycle increases to up to 340 days at 18 months (Psachoulia et al., 2009; Young et al., 2013). This almost linear relationship between age and cell cycle implies a lengthening by about $16 \mathrm{~h}$ every day starting at birth (Young et al., 2013), that is, every cell cycle is two thirds longer than the previous one. Finally, cell cycle in the gray matter of the spinal cord is significantly shorter than in the cortex with OPC dividing every 8 or 27 days at 3 weeks or 2 months postnatal, respectively (Table 1) (Young et al., 2013). With regard to the proportion of OPC that divide to proliferate as opposed to generate mature oligodendrocytes, different studies led to different estimations while consistently reporting higher 
values for the white matter both in the brain and spinal cord with both declining during aging (Rivers et al., 2008; Psachoulia et al., 2009; Kang et al., 2010; Simon et al., 2011; Zhu et al., 2011; Young et al., 2013).

In conclusion, OPC exhibit a remarkably longer cell cycle than neurogenic precursors, which to our opinion reflects long periods of quiescence followed by re-entry in a cell cycle that is a fraction of the total inter-mitotic time. Moreover, the cell cycle of OPC differs between gray and white matter, which is possibly explained by region-specific differences as revealed by transplantation experiments (Vigano et al., 2013).

\section{CELL CYCLE IN PATHOLOGICAL CONDITIONS}

Accumulating evidence indicates that OPC play key roles during brain injury (Nguyen et al., 2006; Huang et al., 2011; Zhang et al., 2013). Demyelination in multiple sclerosis leads to impaired saltatory signal conduction and loss of axon integrity (Huang et al., 2011). OPC react by migrating into the lesion and differentiate in mature myelinating oligodendrocytes and Schwann cells (Zawadzka et al., 2010). This reaction enhances recovery and is known to decrease with age making it a potential target for regenerative therapies (Nguyen et al., 2006; Zawadzka et al., 2010; Huang et al., 2011; Deshmukh et al., 2013).

Stab wound in the cortex increases proliferation in the whole brain with a five-fold higher response in the ipsilateral compared to contralateral hemisphere 3 days post injury (Simon et al., 2011). In particular, at 1 week $74 \%$ of OPC cycle suggesting that cells enter the cell cycle from quiescence and, concomitantly, shorten the G1-phase of their cell cycle (Simon et al., 2011).

Cerebral ischemia has a strong impact on oligodendrocytes since they lack the ability to proliferate and, once damaged, to myelinate axons (McTigue and Tripathi, 2008). After stroke resident and SVZ-derived OPC start to proliferate and migrate to the penumbra where they differentiate into mature oligodendrocytes that myelinate newly sprouted axons thus enhancing neuronal survival and short-term synaptic plasticity (Zhang and Chopp, 2009; Ueno et al., 2012; Zhang et al., 2013) and preclinical studies showed improved healing of stroke after pharmaceutically enhanced oligodendrogenesis (Zhang et al., 2013).

Most studies have focused on neuronal aspects of brain recovery and the role of other cell types awaits further investigation. Only recently studies started to focus on cell cycle parameters of OPC and other cell types such as astrocytes and pericytes playing critical roles in disease including glial scar formation and inflammation (Goritz et al., 2011; Lambertsen et al., 2012).

\section{DISCUSSION}

Decades of cell cycle measurements during development have been instrumental to understand and manipulate the contribution of neural precursors in the mammalian brain (Fujita, 1962; Schultze and Korr, 1981; Takahashi et al., 1995; Dehay and Kennedy, 2007; Salomoni and Calegari, 2010; Borrell and Calegari, in press). Studies during adulthood have just begun and parallelisms between the two contexts are hard to identify due to our limited understanding of adult lineages and difficulties in assessing cell cycle and quiescence. Notably, during development progenitors have longer cell cycles than stem cells (Borrell and
Calegari, in press). Yet, differences of greater significance were found by comparing cells undergoing proliferative vs. differentiative division within these two populations (Calegari et al., 2005; Arai et al., 2011). Hence, analyses of, say, type 1/B vs. 2/C cells can only reveal part of the truth with identification of proliferative vs. differentiative precursors within each type being perhaps more important. Moreover, independently from physiological correlations between cell cycle and stemness, it is clear that artificial manipulations can still be effective in increasing stem cell expansion since these can override physiological processes as indicated by studies on NSC and OPC (Artegiani et al., 2011; Beukelaers et al., 2011a; Caillava et al., 2011; Nobs et al., 2013).

It is premature to know whether manipulation of neural precursors will ever allow practical and efficient means toward effective therapy, but the history of cell cycle measurements during development suggests that this may pave a promising road. To achieving this goal, technical limitations need first to be overcome including the identification of markers for the relevant cell types, establishing behavioral tests reflecting functional recovery rather than compensatory learning (Hicks et al., 2009) and animal models of disease faithfully recapitulating the human condition. As one example of the latter, models of stroke often involve the striatum whereas human ischemia mainly affects cortical areas while the few that involve the striatum cause mild deficits (Delavaran et al., 2013). Moreover, modeling disease is often done in young mice while most neurodegenerative diseases are relevant during aging, which has major effects on cell cycle and neurogenesis (Artegiani and Calegari, 2012). We envision that improvements in these aspects of biomedical research will have the greatest impact in the field and hope that this review will help readers to identify, hence overcome, some of our current limitations.

\section{ACKNOWLEDGMENTS}

The authors were supported by the CRTD, the TU-Dresden, ERANET NEURON, BMBF, RENEW IT and the DFG Collaborative Research Center SFB655 (subproject A20). The authors declare no conflict of interest.

\section{REFERENCES}

Altman, J. (1962). Are new neurons formed in the brains of adult mammals? Science 135, 1127-1128. doi: 10.1126/science.135.3509.1127

Aponso, P. M., Faull, R. L., and Connor, B. (2008). Increased progenitor cell proliferation and astrogenesis in the partial progressive 6hydroxydopamine model of Parkinson's disease. Neuroscience 151, 1142-1153. doi: 10.1016/j.neuroscience.2007.11.036

Arai, Y., Pulvers, J. N., Haffner, C., Schilling, B., Nusslein, I., Calegari, F., et al. (2011). Neural stem and progenitor cells shorten S-phase on commitment to neuron production. Nat. Commun. 2, 154. doi: 10.1038/ ncomms 1155

Artegiani, B., and Calegari, F. (2012). Age-related cognitive decline: can neural stem cells help us? Aging 4, 176-186.

Artegiani, B., Lindemann, D., and Calegari, F. (2011). Overexpression of cdk4 and cyclinD1 triggers greater expansion of neural stem cells in the adult mouse brain. J. Exp. Med. 208, 937-948. doi: 10.1084/jem. 20102167

Arvidsson, A., Collin, T., Kirik, D., Kokaia, Z., and Lindvall, O. (2002). Neuronal replacement from endogenous precursors in the adult brain after stroke. Nat. Med. 8, 963-970. doi: 10.1038/nm747

Bergles, D. E., Roberts, J. D., Somogyi, P., and Jahr, C. E. (2000). Glutamatergic synapses on oligodendrocyte precursor cells in the hippocampus. Nature 405, 187-191. doi: 10.1038/35012083 
Beukelaers, P., Vandenbosch, R., Caron, N., Nguyen, L., Belachew, S., Moonen, G., et al. (2011a). Cdk6-dependent regulation of G(1) length controls adult neurogenesis. Stem cells 29, 713-724. doi: 10.1002/ stem.616

Beukelaers, P., Vandenbosch, R., Caron, N., Nguyen, L., Moonen, G., and Malgrange, B. (2011b). Cycling or not cycling: cell cycle regulatory molecules and adult neurogenesis. Cell. Mol. Life Sci. 69, 1493-1503. doi: 10.1007/s00018011-0880-6

Bonaguidi, M. A., Wheeler, M. A., Shapiro, J. S., Stadel, R. P., Sun, G. J., Ming, G. L., et al. (2011). In vivo clonal analysis reveals self-renewing and multipotent adult neural stem cell characteristics. Cell 145, 1142-1155. doi: 10.1016/j.cell.2011.05.024

Borrell, V., and Calegari, F. (in press). Mechanisms of brain evolution: regulation of neural progenitor cell diversity and cell cycle length. Neurosci Res.

Brandt, M. D., Hubner, M., and Storch, A. (2012). Brief report: adult hippocampal precursor cells shorten S-phase and total cell cycle length during neuronal differentiation. Stem cells 30, 2843-2847. doi: 10.1002/stem.1244

Caillava, C., Vandenbosch, R., Jablonska, B., Deboux, C., Spigoni, G., Gallo, V., et al. (2011). Cdk2 loss accelerates precursor differentiation and remyelination in the adult central nervous system. J. Cell Biol. 193, 397-407. doi: $10.1083 /$ jcb.201004146

Calegari, F., Haubensak, W., Haffner, C., and Huttner, W. B. (2005). Selective lengthening of the cell cycle in the neurogenic subpopulation of neural progenitor cells during mouse brain development. J. Neurosci. 25, 6533-6538. doi: 10.1523/JNEUROSCI.0778-05.2005

Calegari, F., and Huttner, W. B. (2003). An inhibition of cyclin-dependent kinases that lengthens, but does not arrest, neuroepithelial cell cycle induces premature neurogenesis. J. Cell Sci. 116, 4947-4955. doi: 10.1242/jcs. 00825

Cameron, H. A., and McKay, R. D. (2001). Adult neurogenesis produces a large pool of new granule cells in the dentate gyrus. J. Comp. Neurol. 435, 406-417. doi: $10.1002 /$ cne. 1040

Carlen, M., Meletis, K., Goritz, C., Darsalia, V., Evergren, E., Tanigaki, K., et al. (2009). Forebrain ependymal cells are Notch-dependent and generate neuroblasts and astrocytes after stroke. Nat. Neurosci. 12, 259-267. doi: $10.1038 / \mathrm{nn} .2268$

Dash, P. K., Mach, S. A., and Moore, A. N. (2001). Enhanced neurogenesis in the rodent hippocampus following traumatic brain injury. J. Neurosci. Res. 63, 313-319. doi: 10.1002/1097-4547(20010215)63:4\%3C313::AIDJNR1025\%3E3.3.CO;2-W

Dawson, M. (2003). NG2-expressing glial progenitor cells: an abundant and widespread population of cycling cells in the adult rat CNS. Mol. Cell. Neurosci. 24, 476-488. doi: 10.1016/S1044-7431(03)00210-0

Dehay, C., and Kennedy, H. (2007). Cell-cycle control and cortical development. Nat. Rev. Neurosci. 8, 438-450. doi: 10.1038/nrn2097

Delavaran, H., Sjunnesson, H., Arvidsson, A., Lindvall, O., Norrving, B., Van Westen, D., et al. (2013). Proximity of brain infarcts to regions of endogenous neurogenesis and involvement of striatum in ischaemic stroke. Eur. J. Neurol. 20, 473-479. doi: 10.1111/j.1468-1331.2012.03877.x

Deng, W., Aimone, J. B., and Gage, F. H. (2010). New neurons and new memories: how does adult hippocampal neurogenesis affect learning and memory? Nat. Rev. Neurosci. 11, 339-350. doi: 10.1038/nrn2822

Deshmukh, V. A., Tardif, V., Lyssiotis, C. A., Green, C. C., Kerman, B., Kim, H. J., et al. (2013). A regenerative approach to the treatment of multiple sclerosis. Nature 502, 327-332. doi: 10.1038/nature 12647

Doetsch, F., Caille, I., Lim, D. A., Garcia-Verdugo, J. M., and Alvarez-Buylla, A. (1999). Subventricular zone astrocytes are neural stem cells in the adult mammalian brain. Cell 97, 703-716. doi: 10.1016/S0092-8674(00) 80783-7

Doetsch, F., Verdugo, J. M., Caille, I., Alvarez-Buylla, A., Chao, M. V., and CasacciaBonnefil, P. (2002). Lack of the cell-cycle inhibitor p27Kipl results in selective increase of transit-amplifying cells for adult neurogenesis. J. Neurosci. 22, 2255-2264.

Encinas, J. M., Michurina, T. V., Peunova, N., Park, J. H., Tordo, J., Peterson, D. A., et al. (2011). Division-coupled astrocytic differentiation and age-related depletion of neural stem cells in the adult hippocampus. Cell Stem Cell 8, 566-579. doi: 10.1016/j.stem.2011.03.010

Fujita, S. (1962). Kinetics of cellular proliferation. Exp. Cell Res. 28, 52-60. doi: 10.1016/0014-4827(62)90311-7
Fumagalli, M., Daniele, S., Lecca, D., Lee, P. R., Parravicini, C., Fields, R. D., et al. (2011). Phenotypic changes, signaling pathway, and functional correlates of GPR17-expressing neural precursor cells during oligodendrocyte differentiation. J. Biol. Chem. 286, 10593-10604. doi: 10.1074/jbc.M110. 162867

Goritz, C., Dias, D. O., Tomilin, N., Barbacid, M., Shupliakov, O., and Frisen, J. (2011). A pericyte origin of spinal cord scar tissue. Science 333, 238-242. doi: 10.1126/science. 1203165

Hicks, A., Schallert, T., and Jolkkonen, J. (2009). Cell-based therapies and functional outcome in experimental stroke. Cell Stem Cell 5, 139-140. doi: 10.1016/j.stem.2009.07.009

Hou, S. W., Wang, Y. Q., Xu, M., Shen, D. H., Wang, J. J., Huang, F., et al. (2008). Functional integration of newly generated neurons into striatum after cerebral ischemia in the adult rat brain. Stroke 39, 2837-2844. doi: 10.1161/STROKEAHA.107.510982

Huang, J. K., Fancy, S. P., Zhao, C., Rowitch, D. H., Ffrench-Constant, C., and Franklin, R. J. (2011). Myelin regeneration in multiple sclerosis: targeting endogenous stem cells. Neurotherapeutics 8, 650-658. doi: 10.1007/s13311-0110065-x

Hughes, E. G., Kang, S. H., Fukaya, M., and Bergles, D. E. (2013). Oligodendrocyte progenitors balance growth with self-repulsion to achieve homeostasis in the adult brain. Nat. Neurosci. 16, 668-676. doi: 10.1038/nn.3390

Jin, K., Wang, X., Xie, L., Mao, X. O., and Greenberg, D. A. (2010). Transgenic ablation of doublecortin-expressing cells suppresses adult neurogenesis and worsens stroke outcome in mice. Proc. Natl. Acad. Sci. U.S.A. 107, 7993-7998. doi: 10.1073/pnas.1000154107

Jin, K., Wang, X., Xie, L., Mao, X. O., Zhu, W., Wang, Y., et al. (2006). Evidence for stroke-induced neurogenesis in the human brain. Proc. Natl. Acad. Sci. U.S.A. 103, 13198-13202. doi: 10.1073/pnas.0603512103

Kang, S. H., Fukaya, M., Yang, J. K., Rothstein, J. D., and Bergles, D. E. (2010). $\mathrm{NG} 2+\mathrm{CNS}$ glial progenitors remain committed to the oligodendrocyte lineage in postnatal life and following neurodegeneration. Neuron 68, 668-681. doi: 10.1016/j.neuron.2010.09.009

Kempermann, G. (2008). The neurogenic reserve hypothesis: what is adult hippocampal neurogenesis good for? Trends Neurosci. 31, 163-169. doi: 10.1016/j.tins.2008.01.002

Kempermann, G., Jessberger, S., Steiner, B., and Kronenberg, G. (2004). Milestones of neuronal development in the adult hippocampus. Trends Neurosci. 27, 447-452. doi: 10.1016/j.tins.2004.05.013

Kessaris, N., Fogarty, M., Iannarelli, P., Grist, M., Wegner, M., and Richardson, W. D. (2006). Competing waves of oligodendrocytes in the forebrain and postnatal elimination of an embryonic lineage. Nat. Neurosci. 9, 173-179. doi: $10.1038 / \mathrm{nn} 1620$

Kriegstein, A., and Alvarez-Buylla, A. (2009). The glial nature of embryonic and adult neural stem cells. Annu. Rev. Neurosci. 32, 149-184. doi: 10.1146/annurev.neuro.051508.135600

Lambertsen, K. L., Biber, K., and Finsen, B. (2012). Inflammatory cytokines in experimental and human stroke. J. Cereb. Blood Flow Metab. 32, 1677-1698. doi: $10.1038 /$ jcbfm.2012.88

Lange, C., Huttner, W. B., and Calegari, F. (2009). Cdk4/cyclinD1 overexpression in neural stem cells shortens G1, delays neurogenesis, and promotes the generation and expansion of basal progenitors. Cell Stem Cell 5, 320-331. doi: 10.1016/j.stem.2009.05.026

Li, G., Fang, L., Fernandez, G., and Pleasure, S. J. (2013). The ventral hippocampus is the embryonic origin for adult neural stem cells in the dentate gyrus. Neuron 78, 658-672. doi: 10.1016/j.neuron.2013.03.019

Lois, C., and Alvarez-Buylla, A. (1994). Long-distance neuronal migration in the adult mammalian brain. Science 264, 1145-1148. doi: 10.1126/science. 8178174

Love, S. (2003). Neuronal expression of cell cycle-related proteins after brain ischaemia in man. Neurosci. Lett. 353, 29-32. doi: 10.1016/j.neulet.2003. 09.004

Lugert, S., Basak, O., Knuckles, P., Haussler, U., Fabel, K., Gotz, M., et al. (2010). Quiescent and active hippocampal neural stem cells with distinct morphologies respond selectively to physiological and pathological stimuli and aging. Cell Stem Cell 6, 445-456. doi: 10.1016/j.stem.2010.03.017

McTigue, D. M., and Tripathi, R. B. (2008). The life, death, and replacement of oligodendrocytes in the adult CNS. J. Neurochem. 107, 1-19. doi: 10.1111/j.1471-4159.2008.05570.x 
Mecha, M., Feliu, A., Carrillo-Salinas, F. J., Mestre, L., and Guaza, C. (2013). Mobilization of progenitors in the subventricular zone to undergo oligodendrogenesis in the Theiler's virus model of multiple sclerosis: implications for remyelination at lesions sites. Exp. Neurol. 250, 348-352. doi: 10.1016/j.expneurol.2013.10.011

Menn, B., Garcia-Verdugo, J. M., Yaschine, C., Gonzalez-Perez, O., Rowitch, D., and Alvarez-Buylla, A. (2006). Origin of oligodendrocytes in the subventricular zone of the adult brain. J. Neurosci. 26, 7907-7918. doi: 10.1523/JNEUROSCI.129906.2006

Merkle, F. T., Tramontin, A. D., Garcia-Verdugo, J. M., and Alvarez-Buylla, A. (2004). Radial glia give rise to adult neural stem cells in the subventricular zone. Proc. Natl. Acad. Sci. U.S.A. 101, 17528-17532. doi: 10.1073/pnas. 0407893101

Ming, G. L., and Song, H. (2011). Adult neurogenesis in the mammalian brain: significant answers and significant questions. Neuron 70, 687-702. doi: 10.1016/j.neuron.2011.05.001

Minger, S. L., Ekonomou, A., Carta, E. M., Chinoy, A., Perry, R. H., and Ballard, C. G. (2007). Endogenous neurogenesis in the human brain following cerebral infarction. Regen. Med. 2, 69-74. doi: 10.2217/17460751.2.1.69

Mirzadeh, Z., Merkle, F. T., Soriano-Navarro, M., Garcia-Verdugo, J. M., and Alvarez-Buylla, A. (2008). Neural stem cells confer unique pinwheel architecture to the ventricular surface in neurogenic regions of the adult brain. Cell Stem Cell 3, 265-278. doi: 10.1016/j.stem.2008.07.004

Nguyen, L., Borgs, L., Vandenbosch, R., Mangin, J. M., Beukelaers, P., Moonen, G., et al. (2006). The Yin and Yang of cell cycle progression and differentiation in the oligodendroglial lineage. Ment. Retard. Dev. Disabil. Res. Rev. 12, 85-96. doi: 10.1002/mrdd.20103

Nobs, L., Nestel, S., Kulik, A., Nitsch, C., and Atanasoski, S. (2013). Cyclin D1 is required for proliferation of Olig2-expressing progenitor cells in the injured cerebral cortex. Glia 61, 1443-1455. doi: 10.1002/glia.22533

Osuga, H., Osuga, S., Wang, F., Fetni, R., Hogan, M. J., Slack, R. S., et al. (2000). Cyclin-dependent kinases as a therapeutic target for stroke. Proc. Natl. Acad. Sci. U.S.A. 97, 10254-10259. doi: 10.1073/pnas.170144197

Palmer, T. D., Willhoite, A. R., and Gage, F. H. (2000). Vascular niche for adult hippocampal neurogenesis. J. Com. Neurol. 425, 479-494. doi: 10.1002/10969861(20001002)425:4\%3C479::AID-CNE2\%3E3.0.CO;2-3

Petreanu, L., and Alvarez-Buylla, A. (2002). Maturation and death of adult-born olfactory bulb granule neurons: role of olfaction. J. Neurosci. 22, 6106-6113.

Pilaz, L. J., Patti, D., Marcy, G., Ollier, E., Pfister, S., Douglas, R. J., et al. (2009). Forced G1-phase reduction alters mode of division, neuron number, and laminar phenotype in the cerebral cortex. Proc. Natl. Acad. Sci. U.S.A. 106, 21924-21929. doi: 10.1073/pnas.0909894106

Ponti, G., Obernier, K., Guinto, C., Jose, L., Bonfanti, L., and Alvarez-Buylla, A. (2013). Cell cycle and lineage progression of neural progenitors in the ventricular-subventricular zones of adult mice. Proc. Natl. Acad. Sci. U.S.A. 110, E1045-E1054. doi: 10.1073/pnas.1219563110

Psachoulia, K., Jamen, F., Young, K. M., and Richardson, W. D. (2009). Cell cycle dynamics of NG2 cells in the postnatal and ageing brain. Neuron Glia Biol. 5, 57-67. doi: 10.1017/S1740925X09990354

Rashidian, J., Iyirhiaro, G. O., and Park, D. S. (2007). Cell cycle machinery and stroke. Biochim. Biophys. Acta 1772, 484-493. doi: 10.1016/j.bbadis.2006.11.009

Rasmussen, S., Imitola, J., Ayuso-Sacido, A., Wang, Y., Starossom, S. C., Kivisakk, P., et al. (2011). Reversible neural stem cell niche dysfunction in a model of multiple sclerosis. Ann. Neurol. 69, 878-891. doi: 10.1002/ana.22299

Richardson, W. D., Kessaris, N., and Pringle, N. (2006). Oligodendrocyte wars. Nature Rev. Neurosci 7, 11-18. doi: 10.1038/nrn1826

Richardson, W. D., Young, K. M., Tripathi, R. B., and McKenzie, I. (2011). NG2glia as multipotent neural stem cells: fact or fantasy? Neuron 70, 661-673. doi: 10.1016/j.neuron.2011.05.013

Rivers, L. E., Young, K. M., Rizzi, M., Jamen, F., Psachoulia, K., Wade, A., et al. (2008). PDGFRA/NG2 glia generate myelinating oligodendrocytes and piriform projection neurons in adult mice. Nat. Neurosci. 11, 1392-1401. doi: 10.1038/nn.2220

Salomoni, P., and Calegari, F. (2010). Cell cycle control of mammalian neural stem cells: putting a speed limit on G1. Trends Cell Biol. 5, 332-342. doi: 10.1016/j.tcb.2010.01.006

Schultze, B., and Korr, H. (1981). Cell kinetic studies of different cell types in the developing and adult brain of the rat and the mouse: a review. Cell Tissue Kinet. $14,309-325$.
Seri, B., Garcia-Verdugo, J. M., McEwen, B. S., and Alvarez-Buylla, A. (2001). Astrocytes give rise to new neurons in the adult mammalian hippocampus. J. Neurosci. 21, 7153-7160.

Shen, Q., Wang, Y., Kokovay, E., Lin, G., Chuang, S. M., Goderie, S. K., et al. (2008). Adult SVZ stem cells lie in a vascular niche: a quantitative analysis of niche cellcell interactions. Cell Stem Cell 3, 289-300. doi: 10.1016/j.stem.2008.07.026

Simon, C., Gotz, M., and Dimou, L. (2011). Progenitors in the adult cerebral cortex: cell cycle properties and regulation by physiological stimuli and injury. Glia 59, 869-881. doi: 10.1002/glia.21156

Stevens, B., Porta, S., Haak, L. L., Gallo, V., and Fields, R. D. (2002). Adenosine: a neuron-glial transmitter promoting myelination in the CNS in response to action potentials. Neuron 36, 855-868. doi: 10.1016/S0896-6273(02)01067-X

Sun, C., Sun, H., Wu, S., Lee, C. C., Akamatsu, Y., Wang, R. K., et al. (2013). Conditional ablation of neuroprogenitor cells in adult mice impedes recovery of poststroke cognitive function and reduces synaptic connectivity in the perforant pathway. J. Neurosci. 33, 17314-17325. doi: 10.1523/JNEUROSCI.2129-13.2013

Takahashi, T., Nowakowski, R. S., and Caviness, V. S. Jr. (1995). The cell cycle of the pseudostratified ventricular epithelium of the embryonic murine cerebral wall. J. Neurosci. 15, 6046-6057.

Tattersfield, A. S., Croon, R. J., Liu, Y. W., Kells, A. P., Faull, R. L., and Connor, B. (2004). Neurogenesis in the striatum of the quinolinic acid lesion model of Huntington's disease. Neuroscience 127, 319-332. doi: 10.1016/j.neuroscience.2004.04.061

Tavazoie, M., van der Veken, L., Silva-Vargas, V., Louissaint, M., Colonna, L., Zaidi, B., et al. (2008). A specialized vascular niche for adult neural stem cells. Cell Stem Cell 3, 279-288. doi: 10.1016/j.stem.2008.07.025

Thored, P., Arvidsson, A., Cacci, E., Ahlenius, H., Kallur, T., Darsalia, V., et al. (2006). Persistent production of neurons from adult brain stem cells during recovery after stroke. Stem Cells 24, 739-747. doi: 10.1634/stemcells.2005-0281

Tsai, H. H., Li, H., Fuentealba, L. C., Molofsky, A. V., Taveira-Marques, R., Zhuang, H., et al. (2012). Regional astrocyte allocation regulates CNS synaptogenesis and repair. Science 337, 358-362. doi: 10.1126/science.1222381

Ueno, Y., Chopp, M., Zhang, L., Buller, B., Liu, Z., Lehman, N. L., et al. (2012). Axonal outgrowth and dendritic plasticity in the cortical peri-infarct area after experimental stroke. Stroke 43, 2221-2228. doi: 10.1161/STROKEAHA.111.646224

Vigano, F., Mobius, W., Gotz, M., and Dimou, L. (2013). Transplantation reveals regional differences in oligodendrocyte differentiation in the adult brain. Nat. Neurosci. 16, 1370-1372. doi: 10.1038/nn.3503

WHO. (2013). The Top 10 Causes of Death. Available on line at: http://www.who. int/mediacentre/factsheets/fs310/en/

Yamashita, T., Ninomiya, M., Hernandez Acosta, P., Garcia-Verdugo, J. M., Sunabori, T., Sakaguchi, M., et al. (2006). Subventricular zone-derived neuroblasts migrate and differentiate into mature neurons in the post-stroke adult striatum. J. Neurosci. 26, 6627-6636. doi: 10.1523/JNEUROSCI.0149-06.2006

Young, K. M., Psachoulia, K., Tripathi, R. B., Dunn, S. J., Cossell, L., Attwell, D., et al. (2013). Oligodendrocyte dynamics in the healthy adult CNS: evidence for myelin remodeling. Neuron 77, 873-885. doi: 10.1016/j.neuron.2013.01.006

Zawadzka, M., Rivers, L. E., Fancy, S. P., Zhao, C., Tripathi, R., Jamen, F., et al. (2010). CNS-resident glial progenitor/stem cells produce Schwann cells as well as oligodendrocytes during repair of CNS demyelination. Cell Stem Cell 6, 578-590. doi: 10.1016/j.stem.2010.04.002

Zhang, R., Chopp, M., and Zhang, Z. G. (2013). Oligodendrogenesis after cerebral ischemia. Front. Neurosci. 7:201. doi: 10.3389/fncel.2013.00201

Zhang, R. L., Chopp, M., Roberts, C., Jia, L., Wei, M., Lu, M., et al. (2011). Ascl1 lineage cells contribute to ischemia-induced neurogenesis and oligodendrogenesis. J. Cereb. Blood Flow Metab. 31, 614-625. doi: 10.1038/jcbfm.2010.134

Zhang, R. L., Zhang, Z. G., Lu, M., Wang, Y., Yang, J. J., and Chopp, M. (2006). Reduction of the cell cycle length by decreasing G1 phase and cell cycle reentry expand neuronal progenitor cells in the subventricular zone of adult rat after stroke. J. Cereb. Blood Flow Metab. 26, 857-863. doi: 10.1038/sj.jcbfm.9600237

Zhang, R. L., Zhang, Z. G., Roberts, C., Letourneau, Y., Lu, M., Zhang, L., et al. (2008). Lengthening the $G(1)$ phase of neural progenitor cells is concurrent with an increase of symmetric neuron generating division after stroke. J. Cereb. Blood Flow Metab. 28, 602-611. doi: 10.1038/sj.jcbfm.9600556

Zhang, R., Zhang, Z., Wang, L., Wang, Y., Gousev, A., Zhang, L., et al. (2004). Activated neural stem cells contribute to stroke-induced neurogenesis and neuroblast migration toward the infarct boundary in adult rats. J. Cereb. Blood Flow Metab. 24, 441-448. doi: 10.1097/00004647-200404000-00009 
Zhang, Z. G., and Chopp, M. (2009). Neurorestorative therapies for stroke: underlying mechanisms and translation to the clinic. Lancet Neurol. 8, 491-500. doi: 10.1016/S1474-4422(09)70061-4

Zhao, C., Deng, W., and Gage, F. H. (2008). Mechanisms and functional implications of adult neurogenesis. Cell 132, 645-660. doi: 10.1016/j.cell.2008. 01.033

Zhu, X., Hill, R. A., Dietrich, D., Komitova, M., Suzuki, R., and Nishiyama, A. (2011). Age-dependent fate and lineage restriction of single NG2 cells. Development 138, 745-753. doi: 10.1242/dev.047951

Conflict of Interest Statement: The authors declare that the research was conducted in the absence of any commercial or financial relationships that could be construed as a potential conflict of interest.
Received: 20 January 2014; accepted: 10 February 2014; published online: 27 February 2014.

Citation: Bragado Alonso S, Schulze-Steikow M and Calegari F (2014) Cell cycle activity of neural precursors in the diseased mammalian brain. Front. Neurosci. 8:39. doi: 10.3389/fnins.2014.00039

This article was submitted to Neurogenesis, a section of the journal Frontiers in Neuroscience.

Copyright (c) 2014 Bragado Alonso, Schulze-Steikow and Calegari. This is an openaccess article distributed under the terms of the Creative Commons Attribution License (CC BY). The use, distribution or reproduction in other forums is permitted, provided the original author(s) or licensor are credited and that the original publication in this journal is cited, in accordance with accepted academic practice. No use, distribution or reproduction is permitted which does not comply with these terms. 